\title{
Keeping Up the Urban Forest: Predictors of Tree Maintenance in Small Southern Towns in the United States
}

\author{
Bonnie L. Lewis and John G. Boulahanis
}

\begin{abstract}
A mail survey of mayors of small towns in 13 southern states assessed the importance of urban forests and current urban forest practices. Topics covered were local tree management practices, resource allocation, and community influence. The findings, based on the responses of 504 mayors, indicate that small southern towns vary widely in their support of urban and community forests. Descriptive and multivariate analysis showing the relative effects of several predictors of basic tree maintenance indicate that basic solutions are near at hand. A clear linkage of state resources and organizational structure to local tree maintenance supports the important role played by the U.S. Department of Agriculture Forest Service and its support for state agencies. In addition, the particular challenges communities face are outweighed by other factors.
\end{abstract}

Key Words. Small towns; urban and community forestry; urban forest management.

The purpose of this study is to analyze predictors of successful tree maintenance programs among southern U.S. towns. Factors limiting success include inadequate funding, other priorities for spending, rapid tree growth, and pest problems.

Trees have always had value in local Southern culture and history. There are landmark trees in many communities that are linked to their unique culture. Furthermore, the environmental and social benefits of trees are becoming more well-known. Historically, tree maintenance has consisted merely of pruning. Now a large and well-developed body of literature exists describing how to provide technical care as well as how to manage urban and community forests. Federal programs have also been developed to promote research and education.

Despite this plethora of information, we do not know those factors that lead to successful tree maintenance programs. The purpose of this research is to study the factors that are predictive of varying levels of success. Small towns (populations between 5,000 and 25,000) in 13 southern states were selected for study because they fall under the general responsibility of the southern U.S. Department of Agriculture Forest Service and its urban and community forestry (UCF) program. Two sources of data are drawn on: 1) census descriptors; and 2) survey data from mayors of small towns. The basic objective of the survey was to measure the perceived level of importance of urban forests among the mayors and to assess the current management practices used in small communities.

\section{LITERATURE REVIEW}

Urban and community forestry has redirected the study of traditional forestry practices toward the specialized needs of trees in urban areas. Although this literature is fairly well established (Kielbaso 1990; Elmendorf et al 2003; Treiman and Gartner 2004; Watson 2004; Kuhns et al. 2005), what bears review is the concept of sustainability for urban forest programs. Also important are descriptors of current practices in similar small communities.

\section{Urban and Community Forestry Sustainability}

Previous research has identified three components of a sustainability model for communities: vegetative resources in the form of arboriculture expertise, a community framework of social interaction and collaboration, and a geographically/politically bounded area that includes both public and private trees (Clark et al. 1997). For sustainability of urban forests, Dwyer et al. (2003) establishes principles of UCF management that embrace diversity, connectedness, and the ever-changing nature of people and land and plant materials. From this, they define UCF sustainability as the process of "maintaining healthy and functional vegetation and associated systems that provide long-term benefits desired by the community" (Dwyer et al. 2003). They continue by emphasizing the significant role of both managers and users of the urban forest in ensuring its sustainability. From this framework, a successful UCF program would be sensitive to the concerns and involvement of a broad array of community members. Selecting the best organizational structure is also important, because it should reflect both the needs of the community and the forest.

Tree City USA was created in 1976 by The National Arbor Day Foundation for the U.S. Bicentennial celebration specifically to provide UCF resources and a model to towns and cities of all sizes (Tree City USA 2004). The purpose of Tree City USA was to promote the stewardship of tree resources. The requirements for becoming a Tree City USA were kept simple to promote their widespread use. For official recognition, communities were to complete four tasks: 1) form a municipal advisory council that would advise the city council on tree care and promotion; 2) pass a tree care ordinance; 3) establish a community forestry budget of at least $\$ 2$ per capita; and 4) annually proclaim and celebrate Arbor Day. Once recognized, communities could then apply for small grants to carry out tree-related activities or purchase needed equipment. There are currently more than 3,000 communities participating in Tree City USA.

Structural, economic, and social resources are important elements in predicting UCF practices. Dickerson et al. (2001) examined the wealth and educational levels of residents in relation 
to the content of tree ordinances in 151 Illinois communities. They found that greater community wealth and education were associated with more professional management and care of trees. Less wealth and education focused on contracted services and the use of volunteers. They also found that the more highly educated, wealthier communities were more likely to stress maintenance and protection of trees, whereas poorer, less educated communities focused on aesthetics and safety. The communities in their study were both small and large, ranging from 313 to 2.7 million people (median $=15,319$ ).

Some have questioned the extent to which smaller, rural communities are able to practice urban forestry (Groninger et al. 2002). In these communities, the trees are older and often in poor health. Many trees are the same age. Unhealthy tree topping is practiced. Too often the tree population lacks diversity, and often there are too few trees. Reasons cited for poor UCF practices include lack of knowledge, cost, lack of tree inventories, poor utilization of state and federal programs, and unclear rights and responsibilities among power companies, homeowners, and municipalities. Strategies for improvement include linking UCF to the interests of business, increasing education for city leaders and homeowners, encouraging "smart" volunteerism, and providing education about better tree care practices.

The urban forester is seen as a good facilitator for many of these strategies (Straka et al. 2005). Many larger cities use urban foresters, but smaller cities frequently cannot fund such positions. Schroeder et al. (2003) found statistically significant relationships between city size and the likelihood that the city would have a tree board or commission, a street or shade tree ordinance, a tree inventory, a department or employee responsible for public trees, tree ordinance provisions, trained employees working with public trees, comprehensive tree service provision, and active tree programs.

Articles are abundant in the literature on the importance of urban forestry programs and what components are important from the perspective of good forestry practices (Groninger et al. 2002; Elmendorf et al. 2003). There are also empirical studies that describe levels of urban forestry activity and support in different communities (Dickerson et al. 2001 for IL and Elmendorf et al. 2003 for PA and the U.S.). Missing are analyses that determine the relative effects of various factors contributing to sustainable practices.

\section{METHODOLOGY}

In this article, we present basic descriptive findings on current UCF practices among small southern towns. These data are drawn from a mail survey of small-town mayors in 13 states in the United States. Various questions were used to gauge perceptions and practices pertaining to urban tree maintenance. This is followed by linear regression findings that assess which factors are most important in predicting levels of basic tree maintenance used by those towns. Relying on available literature, six contrasting models are formulated and tested. Subsequently is a brief description on survey design, sample quality, and measurement of variables.

\section{Survey Design}

We identified 1,426 small southern towns and cities with populations between 5,000 and 25,000 in the 13 states (AL, AR, FL, GA, KY, LA, MS, NC, OK, SC, TN, TX, and VA). As a result of limited contact information, only 931 surveys were mailed. The "Keeping Up the Urban Forest Survey" was sent to the mayors of these towns. Of these, 504 usable surveys were returned for a response rate of 54\%. The Dillman Design Method (Dillman 2000) was used to conduct the survey relies on a series of five mailings or contacts to the targeted sample. For our purposes, only four contacts were necessary to achieve an appropriate sample size.

\section{Sample Description}

We compared population size, median household income, and state location with 2000 U.S. Census data (Tables 1 and 2). As these tables show, our sample population is similar to the census parameters.

\section{Measurement of Variables}

The literature identifies six factors related to successful tree maintenance (see Table 3). These six factors were analyzed in this study for their relative effects on tree maintenance. After Table 3, we provide greater detail on each factor and the rationale for why it is included in the model.

Structural/demographic factors include community size, median income, and percent with a high school education or higher. At issue is whether these broader structural factors have greater importance than factors that can more easily be manipulated.

Availability of state resources addresses mayors' knowledge of state forestry agencies that provide consulting expertise and resources for small towns with regard to UCF. The state forestry agencies are usually quite active in promoting UCF and distribute funds promoting UCF through Tree City USA grants that they believe will result in sustainability.

Establishing a municipal organizational structure is recommended by urban forestry best management practices for communities. Rather than including individual indicators of the organizational structure, we created an index by combining three questions: 1) whether there is a tree ordinance; 2) a specific department and person responsible for urban forest maintenance; and 3) a budget specifically for tree maintenance. The advantage of using indices is greater statistical variability. Cronbach's alpha is typically used to assess whether a set of items seems to measure some single construct, in this case, organizational structure. It is based on the intercorrelations among the items (Bohrnsted and Knoke 1994). Cronbach's alpha for municipal organizational structure was 0.66 and indicated that the use of this index was appropriate.

Characteristics of the mayor is the next factor included in the model. The mayor in most cases is less fixed than the organizational structure but still instrumental in instituting policy. A frequently cited requirement for successful UCF programs is having an individual who values and promotes trees and tree care. If the mayor, a pivotal person in town politics, values tree main-

Table 1. Comparison of towns in population $(N=1426)$ to sample $(n=504)$.

\begin{tabular}{lcr}
\hline Variable & $\begin{array}{l}2000 \text { census } \\
\text { mean }\end{array}$ & $\begin{array}{c}\text { Sample } \\
\text { mean }\end{array}$ \\
\hline Population size & 11,018 & 11,133 \\
Median household income & $\$ 38,765$ & $\$ 35,080$ \\
Percent with at least a high school degree & $77 \%$ & $75 \%$ \\
\hline
\end{tabular}


Table 2. State-by-state comparison of population to sample.

\begin{tabular}{|c|c|c|c|c|c|}
\hline & $\begin{array}{l}2000 \text { census number of towns } \\
\text { between } 5,000 \text { and } 25,000\end{array}$ & $\begin{array}{l}\text { Towns with } \\
\text { contact information }\end{array}$ & $\begin{array}{l}\text { Percent coverage in } \\
\text { sampling frame }\end{array}$ & $\begin{array}{l}\text { Survey } \\
\text { response }\end{array}$ & $\begin{array}{l}\text { Final percent } \\
\text { response }\end{array}$ \\
\hline Alabama & 88 & 74 & 84.1 & 42 & 56.8 \\
\hline Arkansas & 45 & 40 & 88.9 & 22 & 55.0 \\
\hline Florida & 321 & 108 & 33.6 & 53 & 49.1 \\
\hline Georgia & 107 & 80 & 74.8 & 41 & 51.3 \\
\hline Kentucky & 75 & 63 & 84.0 & 40 & 63.5 \\
\hline Louisiana & 91 & 49 & 53.8 & 29 & 59.2 \\
\hline Mississippi & 57 & 47 & 82.5 & 24 & 51.1 \\
\hline North Carolina & 100 & 87 & 87.0 & 48 & 55.2 \\
\hline Oklahoma & 54 & 52 & 96.3 & 24 & 46.2 \\
\hline South Carolina & 70 & 43 & 61.4 & 33 & 76.7 \\
\hline Tennessee & 79 & 63 & 79.7 & 35 & 55.6 \\
\hline Texas & 245 & 190 & 77.6 & 94 & 49.5 \\
\hline Virginia & 94 & 35 & 37.2 & 19 & 54.3 \\
\hline Total & 1426 & 931 & 65.3 & 504 & 54.1 \\
\hline
\end{tabular}

tenance, one would think that a successful program would result. The mayor was asked to answer a series of value-based questions on the benefits the town receives from its trees. The answers to these items were summed to create an index ( $\alpha=0.69)$. How long the mayor has served, the mayor's gender, and relative importance of tree maintenance as seen for the specific mayor's administration are also included in this category.

One must also recognize that challenges, including such problems as costs of planting and maintenance, liability costs, and storms, are faced differently by towns. These would serve as

Table 3. Factors related to successful tree maintenance.

\begin{tabular}{|c|c|}
\hline Factor & Components and descriptors \\
\hline \multicolumn{2}{|l|}{ Independent variables } \\
\hline \multirow[t]{3}{*}{ Structural/demographic } & $\begin{array}{l}\text { Education (percent high school degree or } \\
\text { more) }\end{array}$ \\
\hline & Income (median household income) \\
\hline & Population size \\
\hline $\begin{array}{l}\text { Availability of state } \\
\text { resources }\end{array}$ & $\begin{array}{l}\text { Mayor's knowledge of state forestry } \\
\text { agency }\end{array}$ \\
\hline \multirow{2}{*}{$\begin{array}{l}\text { Municipal organizational } \\
\text { structure }\end{array}$} & Index, based on whether town has: \\
\hline & $\begin{array}{l}\text { a tree ordinance; } \\
\text { specific department and person } \\
\text { responsible for UCF; or } \\
\text { specific budget for UCF. }\end{array}$ \\
\hline \multirow[t]{4}{*}{ Characteristics of mayor } & $\begin{array}{l}\text { Value of trees to mayor (count of } \\
\text { perceived benefits of trees the mayor } \\
\text { cites) }\end{array}$ \\
\hline & $\begin{array}{l}\text { Importance of tree maintenance for } \\
\text { mayor }\end{array}$ \\
\hline & Years served as mayor \\
\hline & Gender \\
\hline Challenges of maintenance & $\begin{array}{l}\text { Costs of planting, maintenance, } \\
\text { liability/insurance, storm cleanup, } \\
\text { impeding progress, lack of consensus } \\
\text { on assigning tree value }\end{array}$ \\
\hline Community social capital & $\begin{array}{l}\text { Extent of public interest in planting and } \\
\text { maintenance }\end{array}$ \\
\hline \multicolumn{2}{|l|}{ Dependent variable } \\
\hline Basic tree maintenance & $\begin{array}{l}\text { Index based on whether town routinely } \\
\text { performs pruning, mulching, } \\
\text { removal/stump grinding, fertilizing, } \\
\text { and planting }\end{array}$ \\
\hline
\end{tabular}

$\mathrm{UCF}=$ urban and community forestry. mitigating factors. A low Cronbach's alpha level indicated that these items needed to be included separately rather than in scaled format $(\alpha=0.29)$. As noted in Table 3, these include costs of planting, maintenance, liability/insurance, storm cleanup, impeding progress, and lack of consensus in the community on assigning tree value.

To measure the final factor, social capital, mayors were asked to indicate, on a scale of 1 (not influential) to 5 (very influential), how important various persons and groups were for promoting planting and tree maintenance. This included the newspaper, schoolchildren, garden clubs, state urban forester, street maintenance personnel, utility companies, city council members, general population, county extension personnel, churches, urban forest committee, and master gardeners. Scale analysis revealed that this set of questions measured a very strong unidimensional composite $(\alpha=0.85)$.

\section{FINDINGS}

\section{Urban and Community Forestry Tree Maintenance}

The mayors reported the following levels of routine tree maintenance activity: $79 \%$ prune, $58 \%$ mulch, $43 \%$ fertilize, and $47 \%$ remove trees and stumps (Table 4). Less than two-thirds reported either planting trees in the last 5 years or planning to do so in the future. Ten percent of all towns reported not performing any of these activities, whereas $20 \%$ reported performing all of them. On average, communities completed almost three (2.9) of the activities.

\section{Structural, Demographic Factors}

Communities in the study were quite diverse. Educational levels ranged from $21 \%$ to $99 \%$ with high school degrees or more with

Table 4. Tree maintenance practices of communities.

\begin{tabular}{ll}
\hline Tree maintenance activities routinely performed & Percent \\
\hline Pruning & 79 \\
Mulching & 58 \\
Removal/stump grinding & 47 \\
Fertilizing & 43 \\
Major planting in last 5 years or in future & 61 \\
\hline
\end{tabular}


a mean of $75 \%$. The median household incomes were, at minimum, $\$ 12,917$ to a high of $\$ 111,819$ with a mean of $\$ 35,080$.

\section{Availability of State Resources}

When respondents were asked whether there was a state forestry agency that provides consulting expertise and resources for small towns, $66 \%$ said yes, $28 \%$ said they did not know, and $6 \%$ said no. When asked what specific agency they went to, $70 \%$ reported state forestry departments and $14 \%$ cited extension service. Other responses included urban forestry specifically and the state urban forest council. When asked if they had ever been contacted by the state agency, $9 \%$ said yes, $15 \%$ did not know, $16.4 \%$ said no, and $46 \%$ left this question blank.

\section{Municipal Organizational Structure}

Most communities (81\%) have a department for tree maintenance (see Table 5). By far, this responsibility is most frequently located in either public works $(47 \%)$ or parks and recreation $(25 \%)$ departments. At times, responsibility was shared. Most frequent partners were utilities, maintenance, and grounds or building departments. More than half of the communities (59\%) have a specific person responsible for trees, but less than onethird have a dedicated budget (31\%). Almost half (49\%) have passed a tree ordinance. An index of the municipal organizational structure revealed that $12.5 \%$ did not have any of these structures in place, $20.7 \%$ have all of them, and, on average, communities reported having slightly more than two features (2.16).

\section{Characteristics of the Mayor}

A mean of 6.8 years of service was reported by the mayors who responded to the survey. These ranged from 1 month to 54 years in office. In terms of gender, $13.5 \%$ were female with the remaining $86.5 \%$ male. When asked what were the most important issues facing the mayors, on a scale of 1 to 5 with 5 having the most importance, economic development, roads, and crime all had median values of 5 . Rated lowest, with a median of 3 , was tree maintenance. However, when asked to rate what they understood as benefits of trees, the majority of mayors realized that trees provide many benefits. Rated highest were that trees add to the aesthetic beauty of the area $(99 \%)$, improve the town's image (94\%), and improve the overall quality of life (83\%). Lowest were benefits for reducing crime $(9 \%)$, increasing property tax collections through increased assessments (26\%), and adding to business climate (48\%). The tree-valuing index, the sum of all the benefits the mayor felt the town received from its trees, ranged from 0 to 9 and had a mean of 5.47.

\section{Challenges of Maintenance}

Respondents were asked to identify, from a list of challenges, those faced by their communities. Options included the costs of

Table 5. Organizational structure of community urban and community forestry programs.

\begin{tabular}{ll}
\hline Municipal organizational features & Percent \\
\hline Department for tree maintenance & 81 \\
Person for tree maintenance & 59 \\
Budget for tree maintenance & 31 \\
Tree ordinance & 47 \\
\hline
\end{tabular}

planting, costs of maintenance, increased city liability and insurance rates, costs of cleanup related to storms and accidents, impeding progress, and forging a consensus on the value of trees. Of these, the cost of maintenance was the greatest (77\%) followed by cost of cleanup related to storms and accidents $(68 \%)$ and costs of planting (48\%). Of less challenge were increased city liability and insurance rates (19\%) and forging a consensus on the value of trees $(20 \%)$.

\section{Social Capital}

Mayors were asked to indicate, on a scale of 1 (not influential) to 5 (very influential), how important various persons and groups were for promoting planting and tree maintenance. The findings revealed that the most influential group was city council (3.7 out of 5), garden clubs (3.5), general population (3.5), and schoolchildren (3.25). Lowest were churches and the urban forest committee (both 2.6) followed by the state urban forester (2.85). An index of social capital created by adding each group's influence ranged from 0 to 48 with a mean of 24.27 .

\section{Multivariate Analysis}

The most important predictor of tree maintenance was whether an organizational structure was present (Table 6). As noted earlier, the presence of an organizational structure was gauged by whether the city had a department or specific person responsible for tree maintenance, a specific budget for trees, or a tree ordinance in their city. Mayors in cities that had an organizational structure for tree maintenance, while controlling for all other variables, reported more routine tree maintenance activities. Resources at the state level also entered significantly into the model, indicating that mayors who reported knowledge of a state forestry agency were more likely, while controlling for all other variables, to report overall higher levels of tree maintenance.

In addition to city and state resources, the individual characteristics of the mayor also proved to be significant variables in the model. The strongest predictor in this category was whether the mayors felt that tree maintenance is an important issue in their administration. Mayors who rated tree maintenance as an important issue were more likely to report performing higher levels of tree maintenance activities. As an individual characteristic of the mayor, gender proved to be a significant predictor of tree maintenance. Female mayors, while controlling for all other predictors, were more likely to report performing tree maintenance activities when compared with their male counterparts. The number of years served by the mayors and the value they place on trees approached significance in the model as well. Mayors who have more years of service are more likely to report higher tree maintenance activities when compared with those who have fewer years in office. Moreover, there was a positive relationship between the amount of value mayors place on trees and level of tree maintenance activities. In other words, the more benefits the mayors placed in trees, the greater the performance of tree maintenance activities practiced in their towns.

\section{SUMMARY AND DISCUSSION}

This analysis has shown that small southern towns vary widely in their support for UCF and tree maintenance. For some communities, basic urban tree management appears totally lacking, whereas for others, tree maintenance is fully routine. Going beyond basic description, we found that the fourth model was the 
Table 6. Regression analysis showing standardized coefficients among the six models.

\begin{tabular}{|c|c|c|c|c|c|c|}
\hline \multirow[b]{2}{*}{ Variables } & \multicolumn{6}{|c|}{ Models } \\
\hline & 1 & 2 & 3 & 4 & 5 & 6 \\
\hline \multicolumn{7}{|l|}{ Structural/demographic } \\
\hline Income & 0.019 & 0.051 & 0.001 & 0.036 & 0.018 & 0.018 \\
\hline State resources & & $0.258^{\mathrm{w}}$ & $0.159^{\mathrm{x}}$ & $0.111^{\mathrm{y}}$ & $0.107^{y}$ & $0.108^{\mathrm{y}}$ \\
\hline Municipal organization & & & $0.450^{\mathrm{w}}$ & $0.397^{\mathrm{w}}$ & $0.408^{w}$ & $0.409^{w}$ \\
\hline Years served by mayor & & & & $0.081^{\mathrm{z}}$ & 0.078 & 0.078 \\
\hline Gender of mayor & & & & $-0.128^{\mathrm{x}}$ & $-0.139^{\mathrm{x}}$ & $-0.139^{\mathrm{x}}$ \\
\hline Importance of tree maintenance & & & & $0.172^{\mathrm{w}}$ & $0.167^{\mathrm{w}}$ & $0.170^{\mathrm{x}}$ \\
\hline \multicolumn{7}{|l|}{ Challenges of maintenance } \\
\hline Costs of planting & & & & & 0.061 & 0.061 \\
\hline Costs of maintenance & & & & & -0.083 & -0.083 \\
\hline Social capital & & & & & & -0.008 \\
\hline Intercept & 1.730 & 1.592 & 1.220 & 1.052 & 1.328 & 1.361 \\
\hline $\mathrm{R}^{2}$ & 0.013 & 0.079 & 0.263 & 0.320 & 0.331 & 0.331 \\
\hline
\end{tabular}

${ }^{\mathrm{z}} P<0.10,{ }^{\mathrm{y}} P<0.05,{ }^{\mathrm{x}} P<0.01,{ }^{\mathrm{w}} P<0.001$.

best overall predictor of tree maintenance. This model included structural demographic, state resources, municipal organizational structure, and characteristics of the mayor. Models 5 and 6 , which included challenges communities face, and social capital, were not found to have any significant additional explanatory power.

Using model 4, the most statistically significant predictor, controlling for all other variables, was municipal organizational structure; having a person, department, and budget designated for UCF is positively related to the mayor's reports of routine tree maintenance. Second and third statistically significant predictors were characteristics of the mayor: whether he or she saw value in the urban forest and the gender of the mayor. In this case, mayors who saw value in the urban forest were more likely to report routine tree maintenance. Additionally, female mayors were more likely to support routine tree maintenance. Also statistically significant was state resources $(P<0.05)$. The model indicated that increased mayoral knowledge of state urban forest resources was also significantly associated with tree maintenance. Other variables that approach significance and would have probably reached significance, had the sample size been larger, included the extent to which mayors saw benefits in the UCF and the number of years he or she had served as mayor. Mayors who cited more benefits of UCF and who served longer reported more tree maintenance activities.

The findings in this study are interesting in many ways. First, having a person, department, and budget designated for UCF is the most important predictor of routine tree maintenance. The linkage of state resources and their encouragement of communities to set up those organizational structures give evidence for the importance of the role that has been played by U.S. Department of Agriculture Forest Service and their support of state agencies.

Also important is to note which factors were not significant. First, the demographic factors of communities, notably the educational and income levels, were not important. Communities that are poor and wealthy appear to be equally able to practice routine maintenance. Furthermore, although mayors report various challenges such as costs of planting, maintenance, liability/ insurance, cleanup, and other challenges, these proved to be insignificant as well. Lastly, social capital, as we measured it, was not statistically significant. Social capital was measured as the amount of influence of various constituencies had in promoting planting and maintenance. Examples were newspapers, garden clubs, utility companies, city councils, and general public, to name a few. Although individually, these groups may be important, grouped together as a measure of social capital, other factors were more important.

\section{CONCLUDING REMARKS}

The findings in this study are important in several ways. Although many studies have described urban forest practices, no studies, to our knowledge, have attempted to measure the relative effects of various factors that might predict how much small towns and cities perform basic tree maintenance tasks. In doing so, we have identified what is not only important, but also what is not important. First, although it may seem logical that towns with greater community wealth and resources (higher educational levels, higher median incomes) might be better able to support their UCFs, this idea did not prove to be supported. Also not important are the unique challenges faced by communities. What is most significant for successful routine tree maintenance is for towns to have the basic organizational structure in place, including a specific department, person, and budget dedicated to tree maintenance, and having a tree ordinance on record. This is exactly what the UCF literature has been recommending for many years, but now it has been established as the most significant predictor. Although state resources were less important, they, in many cases, are the persons and organizations that have promoted these practices. Lastly, it is now statistically documented that the support of the mayor, with attitudes valuing $\mathrm{UCF}$, and with an understanding of its benefits, result in suc- 
cessful tree maintenance programs. It remains for us to be cautious in drawing conclusions in that although clear and significant factors have been identified, with $33 \%$ of the variation in tree maintenance, there remains $67 \%$ that is explained by other, unmeasured factors.

Acknowledgments. Research funded by the Louisiana Department of Agriculture and Forestry with a grant from the USDA Forest Service. We thank Mary Hughes, former Florida Parishes Social Science Research Center Graduate Research Assistant with the Keeping Up the Urban Forest Project.

\section{LITERATURE CITED}

Bohrnsted, G.W., and D. Knoke. 1994. Statistics for Social Data Analysis. F.E. Peacock Publishers, Inc., Itasca, IL.

Clark, J.R., N.P. Matheny, G. Cross, and V. Wake. 1997. A model of urban forest sustainability. Journal of Arboriculture 23:17-30.

Dickerson, S.D., J.W. Groninger, and J.C. Mangun. 2001. Influences of community characteristics on municipal tree ordinances in Illinois, U.S. Journal of Arboriculture 27:318-325.

Dillman, D.A. 2000. Mail and Internet Surveys: The Taylor Design Method. Wiley, New York, NY.

Dwyer, J.F., D.J. Nowak, and M.H. Noble. 2003. Sustaining urban forests. Journal of Arboriculture 29:49-55.

Elmendorf, W.F., V.J. Cotrone, and J.T. Mullen. 2003. Trends in urban forestry practices, programs, and sustainability: Contrasting a Pennsylvania, U.S., study. Journal of Arboriculture 29:237-248.

Groninger, J.W., D.D. Close, and C.M. Basbman. 2002. Can small, rural communities practice urban forestry? Journal of Forestry 100:23-28.

Kielbaso, J.J. 1990. Trends and issues in city forests. Journal of Arboriculture 16:69-76.

Kuhns, M.R., B. Lee, and D.K. Reiter. 2005. Characteristics of urban forestry programs in Utah, U.S. Journal of Arboriculture 31:285-295.

Tree City USA. Foundation for Better Tree Management. 2004. Tree City USA Bulletin 22. The National Arbor Day Foundation.

Treiman, T., and J. Gartner. 2004. Community forests in Missouri, U.S.: Attitudes and knowledge of local officials. Journal of Arboriculture 30:205-213.

Schroeder, H.W., T.L. Green, and T.J. Howe. 2003. Community tree programs in Illinois, U.S.: A statewide survey and assessment. Journal of Arboriculture 29:218-224.

Straka, T.J. 2005. Individual characteristics affecting participation in urban and community forestry programs in South Carolina, U.S. Journal of Arboriculture 31:131-137.

Watson, W.T. 2004. State of Urban Forestry in the South: Final Report. 6 pp. www.UrbanForestrySouth.org (accessed 2/8/2007).

Bonnie L. Lewis (corresponding author)

Professor of Sociology

Florida Parishes Social Science Research Center

Department of Sociology and Criminal Justice

Southeastern Louisiana University

Hammond, LA 70402, U.S.

blewis@selu.edu
John G. Boulahanis

Assistant Professor of Sociology

Florida Parishes Social Science Research Center

Department of Sociology and Criminal Justice

Southeastern Louisiana University

Hammond, LA 70402, U.S.

jboulahanis@selu.edu

Résumé. Une enquête postale auprès des maires de petites villes de 13 états du Sud des États-Unis a permis d'évaluer l'importance des forêts urbaines et des pratiques courantes en foresterie urbaine. Les sujets couverts concernaient les pratiques locales de gestion des arbres, l'allocation des ressources et l'influence de la communauté. Les résultats, basés sur les réponses de 504 maires, indiquent que les petites villes varient largement quant au support qu'elles accordent à la forêt urbaine et communautaire. Des analyses descriptives et à variables multiples quant aux effets relatifs de plusieurs facteurs de prédiction de l'entretien de base des arbres ont indiqué que les solutions de bases sont à portée de main. Un lien clair entre les ressources de l'état et la structure organisationnelle locale à l'entretien des arbres se dégage et met en évidence le rôle important joué par le Service forestier fédéral américain ainsi que les agences d'état. De plus, des défis particuliers auxquels les communautés font face sont accrus par d'autres facteurs.

Zusammenfassung. Eine schriftliche Umfrage unter den Bürgermeistern von kleinen Städten in 13 südlichen Bundesstaaten untersuchte die Bedeutung von Stadtwäldern und gegenwärtigen Forstpraktiken. Die Themen waren lokale Baummanagement-Praktiken, Resourcenbelegung und die Einflüsse der Gemeinde. Die Ergebnisse, basierend auf den Antworten der 504 Bürgermeister, zeigten, dass kleine SüdstaatenStädte sehr stark variieren in ihrem Support von urbaner Forstwirtschaft. Beschreibende und multivariable Analysen, die den relativen Effekt von verschiedenen Predikatoren auf Grundbaumpflege zeigen, verdeutlichen, dass Lösungen auf der Hand liegen. Eine klare Verbindung von staatlichen Resourcen und organisatorischen Strukturen zur lokalen Baumpflege unterstützt die wichtige Rolle des USDA Forest Service und seiner Unterstützung der staatlichen Agenturen. Auch die besonderen Herausforderungen, die Kommunen hier erleben, werden durch andere Faktoren aufgewogen.

Resumen. Una encuesta por mail a los alcaldes de pequeños pueblos en trece estados del sur de los Estados Unidos evaluó la importancia de los bosques urbanos y las prácticas actuales de dasonomía urbana. Los tópicos cubiertos fueron las prácticas de manejo del arbolado, la distribución de los recursos y la influencia de la comunidad. Los hallazgos, basados en la respuesta de 504 alcaldes, indican que los pequeños pueblos sureños varían ampliamente en su apoyo a los bosques urbanos y comunales (UCF, por sus siglas en inglés). El análisis descriptivo y multivariado enseña los efectos relativos de varios predictores del mantenimiento básico del árbol e indican que las soluciones básicas están a la mano. Una clara liga de los recursos del estado y la estructura organizacional al mantenimiento del árbol argumentan la importancia del papel jugado por el Servicio Forestal USDA y su apoyo por las agencias estatales. Además, los desafíos particulares que las comunidades enfrentan son sopesados por otros factores. 